Інжинірінг». - № а201015861; заявл. 29.12.10; опубл. 12.09.11, Бюл. № 17. - 24 с.

[4] Шестопалов С.В. Оптимизация загрузки ПТЛ элеваторов зерном на основе САУ с коммутируемой структурой / С. В. Шестопалов, В. А. Хобин // Автоматизация технологических и бизнес-процессов. - Одесса, 2015. - № 3. T. 7. - C.17-26.

[5] Гурецкий Х. Анализ и синтез систем управления с запаздыванием [пер. с польского] / Х. Гурецкий // М. : Машиностроение, 1974. - 328 с.

[6] Хобин В.А. Системы гарантирующего управления технологическими агрегатами: основы теории, практика применения / В. А. Хобин // Монография: Одесса: «ТЭС», 2008. - 304 с.

[7] Пат. на винахід 99525 Україна, МПК (2011.01), B65G 17/00, G01R 29/00. Спосіб контролю ступеня завантаження конвеєра / Аннаєв Б. С., Герасимов В. В., Хобін В. А., Кір'язов І. М. і ін.; заявник та патентовласник ТОВ «С-Інжинірінг». - № а201014455; заявл. 03.12.10; опубл. 25.05.12, Бюл. № 10. - 14 с.

References

[1] V.A. Khobin Matematicheskaya model' norii kak ob"yekta upravleniya s izmenyayushchimisya svoystvami. Modelirovaniye protsessa zapolneniya kovshey. Odesa: Nauk. pr. ONAFT, vol. 1, issue 42, pp. 358-368, 2012.

[2] V.A. Khobin Kontseptsiya effektivnogo upravleniya proizvoditel'nost'yu potochno-trasportnykh liniy pri peregruzke zerna. Dnepropetrovsk: Khraneniye i pererabotka zerna, № 10 (148), pp. 26-29, 2011.

[3] B. S. Annayev, V.V. Herasymov, V.A. Khobin, I.M. Kiryazov, S.V. Shestopalov Patent na vynakhid №95887 Ukraine, MPK (2011.01), B65G 17/00, B65G 47/46 (2006.01), B65G 65/42 (2006.01), G01G 11/12 (2006.01). Sposib avtomatychnoho upravlinnya zavantazhennyam potokovo-transportnoyi liniyi sypkykh materialiv. Owner of "SEngineering" Ltd. № a201015861; September 12, 2011.

[4] S.V. Shestopalov V. A. Khobyn Optymyzatsyya zahruzky PTL élevatorov zernom na osnove SAU s kommutyruemoy strukturoy. Odessa: Automation of technological and business processes, vol. 7, issue 3, pp.17-26, 2015.

[5] K.H. Guretskiy Analiz i sintez sistem upravleniya s zapazdyvaniyem [trans. from Polish] M. : Mashinostroyeniye, 328 p., 1974.

[6] V.A. Khobin Systems guaranteeing control of technological units: the fundamentals of the theory, application practice Monograph. Odessa: «TES», 304 p., 2008.

[7] B. S. Annayev, V.V. Herasymov, V.A. Khobin, I.M. Kiryazov, S.V. Shestopalov Patent na vynakhid №99525 Ukraine, MPK (2011.01), B65G 17/00, G01R 29/00. Sposib kontrolyu stupenya zavantazhennya konveyera. Owner of "SEngineering" Ltd. № a201014455; May 25, 2012.

\title{
VOCATIONAL TRAINING OF COMPETITIVE ENGINEERS THROUGH THE USE OF COMPUTER TECHNOLOGIES
}

\author{
Yu. G. Loboda ${ }^{1}$, E.U. Orlova ${ }^{2}$, V.E. Volkov ${ }^{3}$ \\ 1,2,3 Odessa National Academy of Food Technologies, Odessa, Ukraine \\ ORCID: ${ }^{1} 0000-0003-4857-7389,{ }^{2} 0000-0003-1865-4742,{ }^{3} 0000-0002-3990-8126$ \\ E-mail: 1jul.loboda@gmail.com, ${ }^{2}$ olenaorlova69@gmail.com, ${ }^{3}$ viktor@te.net.ua
}

Copyright (C) 2017 by author and the journal "Automation technological and business - processes". This work is licensed under the Creative Commons Attribution International License (CC BY). http://creativecommons.org/licenses/by/4.0/

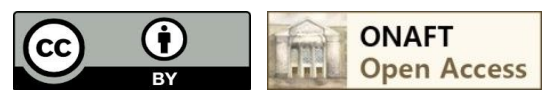

Abstract: The article is concerned with the increasing importance of computer technologies and the need to educate an engineer at the level of modern advances in science and technology. New methods and technologies of learning based on 
the training of competitive engineers are considered. The teaching and methodological support of the didactic process of the professional training for the engineering students is presented and characterized: the motivation tasks for laboratory training and for calculating-and-graphic assignments, the individual card for the organization of the student's work, the methodical guidances. Examples of motivational tasks used for laboratory training are provided: the solution of the search tasks of linear programming, the simulation modeling of the optimal tax rates. The most effective ways to organize learning process using computer technologies for the vocational training of engineering students are indicated.

Keywords: computer system, computer technologies, individual learning pathway individual student card, motivation tasks for laboratory training.

\section{Introduction}

One of the main reasons for unemployment of engineers and devaluation of engineering is decline of the home manufacture in Ukraine. There is only one way to raise social status of engineers (designers, technologists, technicians, automation specialists), to improve their financial situation and to increase inventive, scientific and technical activities in general. This way must be related to the increase in demand for engineering and engineering knowledge. This way also leads to the real improvement of the efficiency of engineering activity as a whole.

On the other hand, the increase in demand for engineering and technical knowledge is impossible without improvement of vocational training for aspiring engineers. There is the feedback between the engineers' level of knowledge (practical knowledge, skills) and their status. So the vocational training of engineering students becomes especially topical today.

The necessity of the effective training of engineers is prompted by global problems of the limited availability of raw materials, energy, economical and human resources. The rapid emergence of the new specialist areas is also an essential stimulating factor in the development of the vocational training for aspiring engineers.

The vocational training of engineering students is a large-scale problem. It is related to various branches of pedagogics, science and industry. The essential aspect of this problem is connected with the study of optimal ways and means for improvements in educational process. Scientific researches for such aspect of the vocational training makes it possible to solve important problems concerning computerization of mechanical engineering, machine building and machinery operating. Computerization is the strategic direction of scientific and technological progress. High professional skills, abilities to make effective and reasonable engineering decisions independently are impossible without mastering computer systems and computer technologies nowadays [1].

Thus universities and academies of technical education have to train engineering students as the computer literate persons. The future engineers must know the main concept of computer technologies. This knowledge ensures competitiveness and professional mobility of engineers. Competitiveness and professional mobility are very important for present circumstances of the market economy in Ukraine.

Problem statement

Computer system is a group of the interconnected devices, at least one of which implements automated data processing.

Computer technology is modern information technology which uses the application of computers and computer systems to store, study, retrieve, transmit, and manipulate data, or information.

The development of computer systems and computer technologies leads to improvement of the vocational training. This in turn is caused by the improvement of the training tools and of the educational process control, by the possibilities for demonstration of research results and their implementation into production, by operative estimating of education and science with correction of their development in accordance with the requirements of industry.

An objective development of pedagogical sciences inevitably leads to looking at new learning technologies and new teaching methods. Nowadays these technologies and methods mostly are based on applications of computers and IT (for example distance learning). But on the other hand computer technologies and computer systems affects pedagogy. The symbiosis between computer science (informatics) and pedagogics creates new branches of science - informational pedagogy and pedagogical informatics (as a part of informational pedagogy).

The problem is to organize effectively learning process using computer technologies and computer systems for the vocational training of engineering students. To solve this problem it is necessary to use pedagogical approaches as well as ITapproaches, thus the solution must be comprehensive and integrated.

The purpose of this study is to substantiate one of the conditions for using of computer technologies and computer systems for the vocational training of engineering students, i.e. implementation of educational and methodical support for structure and contents of the general engineering subjects and special subjects as a way for creation of professional skills and competitiveness of engineering students in the context of global trends and domestic traditions.

The dynamics of the development of modern information and computer technologies for the engineering profile leads to the fact that universities and academies are not able to respond adequately by the appropriate level of training specialists in this field. The current state of affairs can be characterized as the large gap between the level of vocational training of engineering students in the field of information technology and the requirements of the labor market.

The relevance of this study, in addition to what has already been said, is determined by the ever-increasing importance of computer technology and the need to educate an engineer at the level of modern advances in science and technology. 
Recent development and publications analysis where this issue has been addressed

Many of the problems raised in this study have been covered in the works of V.P. Bezpalko, I.M. Bogdanova, A.M. Bogush, B.S. Ghershunskiy, A.P. Yershov, I.M. Zhaldack, Z.N. Curlyand, N.A. Makoyed, I.I. Marchel, Yu. I. Mashbits, V.M. Monahov, I.V. Robert, N.F. Talizina, R.I. Hmeluke and others. In these works psychological, pedagogical and methodological problems of vocational training of aspiring engineers and problems of informatization for the educational environment are analyzed. But these analyses are neither full (if such analyses can be full at all) nor concrete.

There are too many works and textbooks for engineers and engineering students focused on problems of computer technologies. These works and textbooks are too concrete and are not in connection with general problems of the vocational training.

Problem solving

As stated above computer system is a group of the interconnected devices, at least one of which implements automated data processing. But more detailed definition of the computer system states that computer system is the information and technical complex which purpose is processing, storage and input-output of information of all kinds. The computer system includes computers, printers, servers, etc. with their software. Technical, organizational, documentary, functional, algorithmic, software and information structures are used for the computer system description. Problems solved in computer information systems, have a number of characteristic features that affect the technology of automated data processing.

Exchange of information can be realized through the computer network by the local or global data transmission system.

Computer systems and computer technologies have the ability to integrate with other engineering technologies. Computer systems expand the capabilities of engineering systems and technical systems. The computer system is able to create an integrated environment for control due to the diversity and unification of computer equipment.

Computer users have access to different kinds of software, such as system and application software (application software includes compilers, text editors and word processors, database systems, etc.).

Computer systems are very important in the modern world. They are used, practically, in all spheres of society, they have become irreplaceable for the present-day engineers, managers (and not only). It is possible to solve applied tasks in different subject matters and for diverse activities (such as technologies, control, management, accounting, automation of technological and business processes, etc.) thanks to the modern computer systems.

The practical application of computer systems and computer technologies has been found, in particular, for distance learning. Modern IT-technologies changed the meaning of the term «distance learning» principally and fundamentally. Previously, «distance learning» meant only «correspondence education». Now it's a learning tool that uses case studies, TVlearning and network learning technologies.

Computer systems and computer technologies (which are based on the application of computer machinery) provide maximum of opportunities for optimizing the learning process. The combination of various teaching methods, the use of computer systems and technologies for studying of basic training courses, the development of these courses in the framework of standard educational disciplines («Numerical methods», «Database systems and computer networks», «Computer science and information technologies», «Computer Information Systems for Environmental Protection», «Information Computer Technologies in Research», etc.), in our opinion, undoubtedly contributes to the formation of the professional qualities of engineering students.

There is the issue of the impact on the engineers' competences and competency from computer systems and computer technologies.

A wide range of research in competences and competency, both in foreign and domestic pedagogical science, is presented in detail in the works of scientists I.A. Zimov, Yu.G. Tatur, E.F. Zer, I.D. Belonovskaya and others. R.S. Gurevich describes the professional competency as a special organization of knowledge and skills that allows a specialist or an expert to operate successfully in the professional field in all circumstances (even if these circumstances are non-standard or extreme). The formation of the professional competences and professional competency of the engineering students (taking into account all their personalities and originalities) is controlled and regulated process. The effectiveness and success of this process depends on many factors, including the teaching and methodological supply for general engineering subjects and special disciplines.

The teaching and methodological support of the discipline (course) is integration of all its structural components, from which this teaching and methodological support is formed as a whole. These structural components are necessary and sufficient for designing and for qualitative implementation of the process of forming the professional competencies and competency of the aspiring engineer [2].

The activities of a teacher and a student as well as their interactions are the objects of teaching and methodological support. Methodological support contributes to the task of learning from the necessary social and professional experience of mankind by the engineering students. It is the basis of the real educational process.

First of all, let us consider the teaching activities. Analyzing the structure of vocational and pedagogical activity of the teacher of higher education, it is necessary to highlight in this activity a set of elements, which are common for any professional activity. This set of elements includes planning; preparatory work (which is necessary for implementation of the plan), the process of the direct implementation of planned plan, including control and regulation of the implementation and the final stage, which contains an assessment of the results of work [3]. Accordingly, three stages (preparatory, main, final) are combined in the activities of the teacher. These stages change each other consistently. 
At the preparatory stage the teacher consecutively solves such typical professional tasks:

- defines the contents of the learning for the specific training session;

- comprehends and specifies the main aims of learning and development that must be achieved during this training session;

- structure the contents of training, focusing on the main didactic units of educational information to be mastered;

- sets the levels of learners' achievements for every didactic unit;

- forms a plan for delivering lectures, organizing laboratory training and practical exercises;

- verifies necessary material support for educational process.

To solve these problems normative and educational-methodical documentation is required (state requirements for the minimum content and level of training for graduates, curriculum, calendar and thematic plan, etc.). This documentation is used in the activity of the teacher for the correct designing of the didactic process and is included in the standard educational and methodological supply of discipline. Such an opinion is adhered to V.P. Bezpalko [4].

At the main stage of the teacher's activities the task is to get the right knowledge to the engineering students during their training, to organize the independent study (laboratory training, practical exercises, research work, course works), to create the necessary conditions for the learning progress for the main didactic units of educational information at the levels, which are established during designing of the educational process results.

Special methodical tools for teaching are required to fulfill these tasks. The methodical tools for teaching are a set of objects that contain educational information or perform training functions, these tools are designed to form a professional competency of an engineer as a significant quality of his personality (such definition of the methodical tools for teaching is formulated by S.I. Arkhangelskiy). It is not about the replacement of the teacher's functions by a certain set of methodical tools for teaching, but it is about the concrete addition to these functions to enhance the teacher's ability to implement the aims of learning, to fulfill the educational tasks, to form the professional abilities and qualities which are necessary for the personality of the engineer [5].

Let us consider the following methodological tools for teaching: an individual student card, motivation tasks for laboratory and calculation-and-graphic assignments, as well as normative and educational and methodical documentation. These tools are components of the teaching and methodological support of general engineering subjects and special disciplines.

One of the main features of the modern educational process is formation of the individual trajectory of learning (learning pathway, learning curve) almost for every student. To realize such individual learning pathway for a student an individual student card is used.

The individual student card combines some documents. These documents are:

- personal student list, which is saved in the Dean's office or/and in the student personnel department;

- certificate for grades;

- curriculum for the student's specialty and training programs for every training discipline;

- elements of the timetable for training.

The individual student card of course cannot fully replace all these documents. But it enables to show the individual learning pathway for a student.

So the realization of the individual learning pathways for lots of students leads to the sharp increase of the document circulation and the volume of data to be stored. All problems connected with such increase can be solved only by means of computer systems and computer technologies.

An individual learning pathway increases the student's ability to study in a convenient mode. General and special computer disciplines include lectures, laboratory training, practical exercises and (necessarily!) the calculation-and-graphic assignments. In order to complete them successfully in due course the engineering student, being guided by the individual learning pathway, has the opportunity to regulate the time of their execution by himself.

According to our observations the individual learning pathway of the student adjusts him to a serious independent study. It gives the «official» status of independence to the student's mind, it demonstrates that the teacher is interested in the personality of each student, it illustrates respect for student and the teacher's interest in student's problems, concern for successful learning. The individual learning pathway of the student paves the way for professional interaction, providing the possibility of individual correctional and pedagogical support of independent study of the student.

The student operates the educational material by himself. The student learns consciously, getting sound knowledge of different subjects. At the same time, the student's intelligence develops, the ability to self-study, self-education, selforganization is formed. He gets the ability to project the future, to make decisions independently and he gets willingness to bear responsibility for his decisions. Self-control, adequate attitude to the proposed training requirements, self-analysis and other qualities that characterize professional competency develop quickly.

Motivation tasks for laboratory training and calculation-and-graphic assignments allow to master productively general educational subjects and special disciplines. The essence of the motivational task is to stimulate the students' interest to the problem raised, that is focused on the acquirement of specific knowledge. Motivational tasks give an opportunity to demonstrate the practical application of the acquired knowledge, the ability to create independently the new knowledge, to navigate in the information space, to develop critical thinking, that is, to realize the educational purposes of studying general and special disciplines. The motivation tasks for laboratory training and calculation-and-graphic assignments on informatics 
(computer science) are based on one or another subject matter and on the knowledge received by students of the corresponding specialty in this subject area. So, when studying spreadsheets (Excel) and databases (Access) students of technological specialties require knowledge of recipes of mixed fodders or blends of wines, students of economic specialties require knowledge of logistics, mathematics, etc.

Let's give an example of the motivation tasks used for laboratory training in the course «Informatics and Information Technologies». This course is created at the Department of Computer Systems and Business Process Control of Odessa National Academy of FOOD Technologies (ONAFT). All tasks of this type can be solved using spreadsheet Excel.

Example 1. Laboratory training «Solving of the linear programming tasks». This training requires to plan the work of the shop of the dairy plant for the ice cream production. It is known that the shop can make ice cream of two (or more) kinds (different recipes). It is necessary to determine the plan of daily production (that is, the number of tons of output of every type of ice cream), which would bring the maximum profit. It is known that several types of components are used in production (for simplification of milk, milk powder, butter, sugar). The rates of consumption of these products for the production of all types of ice cream and their stocks are known. The profit derived from the sale of one ton of ice cream of each species is known also. It is necessary:

a) to formulate correctly a search task in the form of the linear programming problem;

b) to solve this problem by Excel using the «Find a solution» mode.

Example 2. Laboratory training «Simulation of the optimal tax rate». This laboratory training is focused on the search for an optimal profit tax rate using simulation methods implemented in Excel. It uses the simplest method of searching for a grid of factors. Experiment planning is to change the factors with a constant step and to construct experimental graphs of the rate dependence on the factors. The optimal values of rates are determined not by algorithm (program), but by visual graphs and results of calculations in tables.

Contents of the laboratory training:

1. Build tables in Excel to determine the total budget contributions for 10 years by simulation in variants (different levels of profitability and different sizes of initial capital.

2. Make calculations for different tax rates, recording the results of simulation.

3. Construct the graphical dependence of total revenues in the budget on the size of the tax rate based on the results of calculations.

4. Select the amount of tax that corresponds to the maximum budget contributions.

5. Analyze the situation.

Motivation tasks for the laboratory training and the calculation-and-graphic assignments stimulate independent educational activity, motivation of achievements in mastery of the profession, determine the personal content of professional needs, form the ability to display professional knowledge, strengthening interest in science, scientific researches and cooperation.

The methodical tool that promotes formation the professional competency of the engineering students is a complex of questions, tasks and tests on the organization of self-training and self-control. These questions, tasks and tests are intended for verification of residual knowledge, for thematic, current and final verification of knowledge and skills in general and special disciplines.

Methodological guidances are focused on modular learning technology, which allows the student to study discipline independently, beyond the direct teaching control. The content of methodological guidance includes a discipline plan and its methodological support: a list of topics with control questions, issues of rating control, issues of the final exam on discipline, tests to verify the residual knowledge of discipline, as well as educational literature, available at the ONAFT library for studying the course.

The control questions for each module are deliberately generated in plenty. These questions are detailed, so the student is forced to study the subject in detail. Since the lecture material for this purpose is not enough, then there is a need for their additional extraction. Accordingly there is an accumulation of theoretical knowledge, and the motive of such study is the answer to the control questions and the use of knowledge for the fulfillment of calculation-and-graphic assignments and preparation of examinations.

Each student gets methodological guidance. After acquaintance with guidance student knows how to get started with studying of discipline and what issues are necessary for studying. The set of questions, tests and tasks for self-training allows the student to plan his academic time, to choose consciously the necessary set of knowledge and skills. Thus, the activity and autonomy of the engineering student are supported.

Conclusions

Thus, the presented material specifies the teaching and methodological support for general and special disciplines and characterizes the teaching tools, which are necessary and sufficient for the formation of the professional competency of the engineering student. It is proved that the most effective ways to organize learning process using computer technologies for the vocational training of engineering students are connected with such methodological tools for teaching as individual student cards, motivation tasks for laboratory training and methodical documentation.

\section{References}

[1] Yu.G. Loboda “Deyaki aspekty zastosuvannya komp'yuterno-intehrovanykh tekhnolohiy u protsesi navchannya”, 
Naukovyy visnyk Pivdennoukrayinskoho derzhavnoho universytetu im. K.D. Ushynskoho, V.9-10, pp. 118-126, 2014.

[2] V.P. Bezpalko, Yu.G. Tatur Sistemno-metodicheskoye obespecheniye uchebno-vospitatelnogo processa podgotovki spetsialistov. M.: Vysshaya shkola, 1989.

[3] V.A. Slastenyn Pedahohyka professyonalnoho obrazovaniya. M: Yzdatelskiy centr "Akademiya", 2004.

[4] V.P. Bezpalko Obrazovaniye $i$ obucheniye s uchastiyem komputerov (Pedagogika tretyego tisyacheletiya). M.: Izdatelstvo Moskovskogo Psikhologo-sotsialnogo instituta; Voronezh: Izdatelstvo NPO «MODEK», 2002.

[5] S.I. Arkhangelskiy Uchebnyy process v vysshey shkole, yego zakonomerniye osnovy i metody. M.: Vyssh. Shkola, 1980.

Література

[1] Лобода Ю.Г. Деякі аспекти застосування комп'ютерно-інтегрованих технологій у процесі навчання / Науковий вісник Південноукраїнського державного університету ім. К.Д. Ушинського, Вип.9-10., 2007. - С.118-126.

[2] Беспалько В.П., Татур Ю.Г. Системно-методическое обеспечение учебно-воспитательного процесса подготовки специалистов. / М.: Высшая школа, 1989.

[3] Сластенин В.А. Педагогика профессионального образования. / М: Издательский центр "Академия", 2004.

[4] Беспалько В.П. Образование и обучение с участием компьютеров (Педагогика третьего тысячелетия). / М: Издательство Московского Психолого-социального института; Воронеж: Издательство НПО «МОДЭК», 2002.

[5] Архангельский С.И. Учебный процесс в высшей школе, его закономерные основы и методы. / М.: Высш. школа, 1980.

\title{
ОСНОВНІ НАПРЯМКИ ТА ПЕРСПЕКТИВИ НАУКОВОГО РОЗВИТКУ ИНЖЕНЕРНОЇ МЕХАНІКИ, АВТОМАТИЗАЦЇ̈ ТА КОМП'ЮТЕРНИХ НАУК В ОДЕСЬКІЙ НАЦІОНАЛЬНІЙ АКАДЕМІЇ ХАРЧОВИХ ТЕХНОЛОГІЙ
}

\author{
Г. Ангелов ${ }^{1}$, В. Волков ${ }^{2}$, О. Кананихіна ${ }^{3}$, А. Соловей $^{4}$, О. Тітлова $^{5}$, Ф. Трішин $^{6}$ \\ 1,2,3,4,5,6 Одеська національна академія харчових технологій \\ ORCID: ${ }^{2} 0000-0002-3990-8126$ \\ E-mail: ${ }^{1}$ sociologia.kafedra@mail.ru, ${ }^{2}$ viktor@te.net.ua, ${ }^{3} \mathrm{k} \_$elni@ukr.net, ${ }^{4}$ solovanat56@mail.ru, ${ }^{5}$ titlova@ukr.net, \\ ${ }^{6}$ kindteacher@mail.ru
}

Copyright (C) 2017 by author and the journal "Automation technological and business - processes".

This work is licensed under the Creative Commons Attribution International License (CC BY).

http://creativecommons.org/licenses/by/4.0/

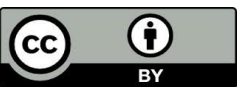

ONAFT

Open Access

Анотація: Розглянуто основні напрямки та перспективи наукового розвитку інженерної механіки, автоматизації та комп'ютерних наук в їх взаємозв'язку. Показано як світові тендениії знаходять своє відображення в історії Одеської національної академії харчових технологій.

Abstract: The main directions and perspectives of scientific development of engineering mechanics, automation and computer sciences are considered in their interconnection. It is shown how world trends are reflected in the history of the Odessa National Academy of Food Technologies.

Ключові слова: механіка, інженерна механіка, механізація, автоматизація, робототехніка, комп’ютерні науки.

Keywords: mechanics, engineering mechanics, mechanization, automation, robotics, computer science.

Вступ

Історія Одеської національної академії харчових технологій (ОНАХТ), її становлення та подальший розвиток нерозривно пов'язані з розвитком інженерної механіки як галузі науки та напрямку освіти. Навчальні плани створеної 